\title{
MANAGEMENT OF CHRONIC FISSURE IN ANO BY KSHARASUTRA (MEDICATED THREAD): A CLINICAL PROSPECTIVE STUDY \\ Gajiram D. Banothe ${ }^{1 *}$, T. S. Dudhamal ${ }^{2}$ \\ ${ }^{1} \mathrm{Ph}$. D. Scholar, Department of Shalya Tantra, IPGT and RA Gujarat Ayurved University, Jamnagar, Gujarat, India \\ ${ }^{2}$ Associate Professor and I/C HOD, Department of Shalya Tantra, IPGT and RA Gujarat Ayurved University, Jamnagar, Gujarat, India
}

Received on: 14/02/20 Accepted on: 12/06/20

\author{
*Corresponding author \\ E-mail: amanbanothe@gmail.com
}

DOI: 10.7897/2277-4343.110487

\begin{abstract}
Parikartika resembles fissure- in- ano as sign and symptoms are same and which is very common among all ano-rectal disorders. Chronic Fissure in ano with sentinel pile and unhealed midline ulcer due to late approach of patients for treatment or failure of conservative treatments of acute condition require surgical intervention. Total 50 patients of chronic fissure- in- ano were selected. Ksharasutra trans-fixation and ligation was done under spinal anaesthesia on sentinel pile with fissure bed after Lord's anal dilatation. After gradual withdrawal of Ksharasutra, the lesion was treated for 4 weeks and outcome was evaluated on the basis of gradation pattern adopted. $95 \%$ relief in pain was observed on 28 th day, whereas $100 \%$ improvement in swelling was found on $14^{\text {th }}$ day and oozing of the wound. $84 \%$ healing was found on $4^{\text {th }}$ week where as $82 \%$ of patients were cured completely. Ksharasutra trans-fixation and ligation in chronic fissure in-ano with sentinel pile after Lord's anal dilatation is a safe with minimum complications and recurrence.
\end{abstract}

Keywords: Chronic fissure- in- ano, Ksharasutra, Lord's anal dilatation, Parikartika

\section{INTRODUCTION}

In Ayurveda, Parikartika is the most common cause of severe burning type of pain in anus during and after defecation resembles with condition fissure-in-ano in modern parlance due to its aetiology and etiopathogenesis. Parikartika means, 'Pari' means all around and 'Kartana' means cutting hence cutting all around the anal canal with pain is most accepted and important clinical symptom. Acute fissure is a linear crack in anoderm which can be easily seen on inspection by separating the buttocks and gentle stretching the anal canal horizontally. Prevalence of this disease is in between 20 to 40 years of age. Female are more commonly affected and the most common site is mid anterior aspect, while in males posterior aspect are more common. This affects unusual site in cases of Crohn's disease and ulcerative colitis. Parikartika is also mentioned in classical as a complication of the Basti (enema) and Virechana (laxation) procedures. ${ }^{1}$ The prevalence rate of chronic fissure-in-ano is approximately $30-40$ of total anorectal sufferings, either because of failure of available conservative treatment or delayed approach of the patients for treatments. In contemporary science, surgical procedure like Lord's anal dilatation, fissurectomy and sphincterotomy are available but they have limitations like recurrence, incontinence etc. ${ }^{2}$ Constipation with passing of hard stool is foremost cause of fissure-in-ano while many diseases manifests as a secondary cause also surgery like haemorrhoidectomy or fistulectomy. In young adults and after delivery in females midline posterior at 6 o'clock position are commonly found. ${ }^{3}$ Two types of Fissure in ano are mentioned i.e. Acute and chronic, in which Acute fissurein-ano is a condition where inflammation of the anal mucosa found and which is mostly cured by conservative treatment. ${ }^{4}$ In chronic cases, there are sentinel pile and unhealed midline ulcer which may be associated with external and internal haemorrhoids and requires surgical correction. ${ }^{5}$ Ksharasutra is gaining its nationwide popularity in day-to-day practice, expanding into Western and European countries. Application of Ksharasutra in Fistula in ano was already established ${ }^{6}$ and it is now time to establish Ksharasutra in other ano-rectal disorders like piles, fistula, fissure etc., most of the research studies are found for the management of Parikartika but almost all are conservative measures. As in chronic fissure-in-ano, surgery is required for complete remission. Application of Ksharasutra gives minimum complication and less recurrence ${ }^{7}$ so in this study Ksharasutra ligation was planned.

\section{MATERIAL AND METHODS}

Total 50 patients, of Parikartika were registered. Standard Apamarga Ksharasutra, Panchavalkala Kwatha for sitz bath, Eranda Bhrishta Haritaki Churna $5 \mathrm{~g}$ at night, Triphala Guggulu Vati and Jatyadi Taila Pichoo (cotton swab soaked in oil) for local holding over the anal region.

Ksharasutra trans-fixation and ligation (KSL) of sentinel pile with fissure bed was done under suitable anaesthesia.

\section{Inclusion criteria}

Diagnosed patients of both sex, age 18-60 years with Parikartika having sign and symptoms like fissure bed with sentinel pile, pain in ano, per rectal bleeding, history of constipation were included in the study after taking informed consent.

\section{Exclusion criteria}

Fissure-in-ano having duration less than 6 weeks, chronic fissurein-ano associated with piles and fistula, Patient below 18 and above 60 years of age. Patients who were suffering from acute 
fissure-in-ano, carcinoma of ano-rectum were not included in this study. Patients suffering from infections like Human Immunodeficiency Virus (HIV), Venereal Disease Research Laboratory (VDRL) and hepatitis-B were also excluded.

\section{Diagnosis criteria}

Patients were diagnosed on the basis of signs and symptoms as per Ayurved and modern literature i.e. Vedana (pain), Malabadhhata (Constipation) and Raktasrava (per rectal bleeding) also on the basis of external findings like position of fissure and external sentinel pile. Digital per rectal examinations $(\mathrm{P} / \mathrm{R})$ were performed with $2 \%$ xylocaine jelly to assess the sphincter tone. Proctoscopic examination was performed after giving appropriate anaesthesia at the time of surgery.

\section{Investigations}

Before surgery, routine blood investigations like $\mathrm{CBC}$, Urine microscopic/macroscopic, BSL (blood sugar levels), KFT (kidney function test), HIV, VDRL and HbSAg and stool examination were carried out prior to the treatment for fitness of the patients for surgery and anaesthesia. Chest X-ray and ECG were carried out in patients over 40 years of age to detect any hidden pathologies related to cardiac or pulmonary functions.

\section{Ethical consideration}

IEC- PGT/7/-A/Ethics/2016-17/3937 Dated 23/02/170.

\section{CTRI registration}

(Clinical Trial Registry of India) vide no. CTRI/2017/10/009963 Dated 03/10/2017.

\section{Preoperative procedure}

The written informed consent was taken prior to the procedure. Patient was kept nil orally for 6 hours. The perianal part was prepared and given soap water enema in the morning at $8 \mathrm{am}$. TT (tetanus toxoid $-0.5 \mathrm{ml}$ intramuscular) and xylocaine $2 \%$ injected intra-dermal for sensitivity test insured before surgery.

\section{Operative Procedure}

After low spinal anaesthesia, the patient was given a lithotomy position, painting and draping was done. As per Lord's anal dilatation procedure, first four fingers anal stretching (anal dilatation) was performed with the help of the lubricated fingers of both hands. ${ }^{8}$ The whole fissure bed including all fibrous tissue and sentinel pile was transfixed and ligated by Ksharasutra with the help of round body curved needle of appropriate size. After proper haemostasis, T-bandage was applied. Patient was then shifted to the ward in conscious and stable condition. The patient was rested down in head low position for 3-4 hour and then permitted to take liquids. Antibiotic and analgesic were given for first three days. Avagaha Swedana (sitz bath) with Panchavalkala Kwatha (PVK) was advised twice a day. From next day of operation, Eranda Bhrishta Haritaki Churna (EBH) - 5 gHS and Triphala Guggulu (TG) tablet - $500 \mathrm{mg}$ TDS (thrice a day) with lukewarm water was prescribed.

\section{Postoperative Procedure}

Dressing was done once a day with instillation of $10 \mathrm{ml}$ Jatyadi Taila (JT) per rectal. Patients were advised to take water intake in excess and fibre rich diet from next day of operation. Patients were assessed after seven days.

\section{Follow up}

Follow up period 30 days after completion of the treatment to observe re-occurrence and any untoward effects.

\section{Assessment criteria}

Assessment was done every seven days to find out the efficacy of Ksharasutra trans-fixation and ligation by relief in postoperative pain, swelling, oozing and days required for complete wound healing.

\section{Statistical Analysis}

Statistical test for the assessment of the result by statistical analysis, student paired t-test and unpaired t-test.

\section{Observations}

In this study, maximum numbers of patients $(38.46 \%)$ were found age group between 31 and 40 years. $55.77 \%$ patients were male and $38.46 \%$ patients were labourer. Maximum patients belong to Hindu religion (90.38\%) and from urban back ground $(51.92 \%)$. Socio-economically middle class patients were more $(94.23 \%)$ and sound sleep was found in $94.23 \%$ of patients. Also in this study maximum patients having Madhyama Koshta (65.38\%) while Mandagani (65.38\%) and Constipation (94.23\%) were found. Vata-Pittaja Prakriti patients were found maximum $(65.38 \%)$ than other. The $86.54 \%$ of patients had observed having irregular bowel habit with Vishamashana (44.23\%) followed by Adhyashana (23.08\%). Totally, $54.84 \%$ of patients having chronicity up to one year and $16.12 \%$ patients were $1-2$ years. The $48.08 \%$ patients were observed with fissure at posterior 6 o'clock position, while 34.62 having fissure at 6 and 12 O'clock position. $57.69 \%$ of patients had sentinel pile at 6 o'clock, $30.78 \%$ patients having sentinel pile at 6 and 12 O'clock both, while $61.54 \%$ patients had spasmodic anal sphincter.

\section{RESULT}

Pain relief was achieved by 28 days in all patients, swelling and oozing had stopped after 14 days. A statistically highly significant $(\mathrm{P}<0.001)$ result has been observed in weekly interval. In case of wound healing, 6 patients required more than 28 days and significant results were seen in weekly interval. The percentage of pain relief on $14^{\text {th }}$ day was $86 \%$ (Table 1 ).

Ksharasutra cut through from fissure bed. Oozing in the form of serous discharge was observed which was assessed every seven days; pain relief showed highly significant result i.e. $\mathrm{p}<0.001$ in every week. hence it can be said that the intensity of Pain decreased day by day and complete pain relief was found in maximum patients on $28^{\text {th }}$ post operative day. In all patients, nonsignificant relief in post-operative swelling was observed by the end of $14^{\text {th }}$ day. After 14 days there was no swelling present in any patients so, there is no need of further statistical evaluation of this data. The swelling due to tissue reaction after operative procedure and so less patients had swelling after operative procedure. Hence non-significant result was found (Table 2).

It reveals that oozing in form of bleeding or serous discharge from post Ksharasutra wound (trans-fixation of skin tag with KS) showed $82.25 \%$ relief within 7 days. From second week non patient had bleeding $\mathrm{P} / \mathrm{R}$. So, there is no need of further statistical evaluation of this data (Table 3 ). 
Gajiram D. Banothe \& T. S. Dudhamal / Int. J. Res. Ayurveda Pharm. 11 (4), 2020

Table 1: Assessment of Post-operative Pain in-ano: $(n=50)$

\begin{tabular}{|c|c|c|c|c|c|c|c|c|c|}
\hline Days & Mean B.T. & Mean A.T. & Mean Diff. & \% Relief & W & S.D. & S.E. & 'P' & \\
\hline $7^{\text {th }}$ & 2.67 & 0.94 & 1.73 & 64.00 & -104 & 0.883 & 0.228 & $<0.001$ & HS \\
\hline $\mathbf{1 4}^{\text {th }}$ & 2.67 & 0.41 & 2.26 & 86.00 & -120 & 0.884 & 0.228 & $<0.001$ & HS \\
\hline $\mathbf{2 1}^{\text {st }}$ & 2.67 & 0.28 & 2.39 & 91.00 & -120 & 0.910 & 0.234 & $<0.001$ & HS \\
\hline $\mathbf{3 0}^{\text {th }}$ & 2.67 & 0.14 & 2.53 & 95.00 & -120 & 0.742 & 0.193 & $<0.001$ & HS \\
\hline $\mathbf{3 0}^{\text {th }}$ & 2.67 & 0.08 & 2.59 & 96.50 & -120 & 0.737 & 0.190 & $<0.001$ & HS \\
\hline
\end{tabular}

B.T. - Before Treatment, A.T. - After Treatment, W - Wilcoxon rank-sum test, S.D.- Standard Deviation, S.E.- Standard error, P - Statistical probability, $(\mathrm{P}<0.001)$

Table 2: Assessment of Post-operative Swelling in ano: $(n=50)$

\begin{tabular}{|c|c|c|c|c|c|c|c|c|c|}
\hline Days & Mean B.T. & Mean A.T. & Mean Diff. & \% Relief & W & S.D. & S.E. & 'P' & \\
\hline $\mathbf{7}^{\text {th }}$ & 0.27 & 0.14 & 0.13 & 78.76 & -3 & 0.354 & 0.090 & 0.500 & NS \\
\hline $\mathbf{1 4}^{\text {th }}$ & 0.27 & 0.00 & 0.27 & 100 & -10 & 0.457 & 0.119 & 0.124 & NS \\
\hline $\mathbf{2 1}^{\text {st }}$ & 0.27 & 0.00 & 0.27 & 100 & - & - & - & - & - \\
\hline $\mathbf{3 0}^{\text {th }}$ & 0.27 & 0.00 & 0.27 & 100 & - & - & - & - & - \\
\hline
\end{tabular}

B.T. - Before Treatment, A.T. - After Treatment, NS - Non-Significant, P > 0.001

Table 3: Assessment of Post-operative oozing in ano

\begin{tabular}{|c|c|c|c|c|c|c|c|c|c|}
\hline Days & Mean B.T. & Mean A.T. & Mean Diff. & \% Relief & W & S.D. & S.E. & 'P' & \\
\hline $\mathbf{7}^{\text {th }}$ & 2.13 & 0.42 & 1.71 & 82.25 & -91 & 1.032 & 0.268 & $<0.001$ \\
\hline $\mathbf{1 4}^{\text {th }}$ & 2.13 & 0.00 & 2.13 & 100 & 120 & 0.990 & 0.255 & $<0.001$ \\
\hline $\mathbf{2 1}^{\text {st }}$ & 2.13 & 0.00 & 2.13 & 100 & - & - & HS \\
\hline $\mathbf{3 0}^{\text {th }}$ & 2.13 & 0.00 & 2.13 & 100 & - & - & - & - & - \\
\hline
\end{tabular}

B.T. - Before Treatment, A.T. - After Treatment, HS - Highly Significant, P $<0.001$

Table 4: Effect of therapies on Vrana Ropana (wound healing)

\begin{tabular}{|c|c|c|}
\hline \multirow{2}{*}{ Wound Healing } & \multicolumn{2}{|c|}{$(\mathbf{n}=\mathbf{5 0})$} \\
\cline { 2 - 3 } & No. of Patient & $\%$ \\
\hline 7 days & 00 & 00.00 \\
\hline 8-14 days & 00 & 00.00 \\
\hline $\mathbf{1 5 - 2 1}$ days & 02 & 4.00 \\
\hline $\mathbf{2 2 - 3 0}$ days & 42 & 84.00 \\
\hline 30 day (5 $^{\text {th }}$ week) & 06 & 12.00 \\
\hline Total & $\mathbf{5 0}$ & $\mathbf{1 0 0}$ \\
\hline
\end{tabular}

\section{Effect of therapies on Vrana Ropana (wound healing)}

It shows that in maximum $84.00 \%$ i.e. 42 patients found wound healing in $4^{\text {th }}$ post-operative week. $4.00 \%$ i.e. 2 patients were taking $3^{\text {rd }}$ week for complete wound healing, while $12.00 \%$ i.e. 6 patients were taking more than 28 day for complete wound healing. None of any patients of got wound healing in 14 days (Table 4).

\section{Overall effect of therapies}

From the present study, it can be concluded that Figure 5 depicts the results of the study in 50 patients of Parikartika clearly shows that 41 patients $(82.00 \%)$ patients were cured and 4 patients $(8.00 \%)$ patients were maximum improved and in 3 patients $(6.00 \%)$ patients were found moderately improved and 2 patients $(4.00 \%)$ patients were mild improvement while no any of the patients showed no relief (Table 5).

\section{DISCUSSION}

In chronic fissure in ano, there are sentinel pile and anal papilla and unhealed midline ulcer which may be associated with pain, bleeding per ano and constipation. In this condition the conservative management is not more effective and needs surgical intervention. Ksharasutra trans-fixation and ligation of chronic fissure in-ano associated with sentinel pile is a safe, ambulatory procedure that is a good alternative to surgical
Table 5: Overall effect of therapies

\begin{tabular}{|c|c|c|}
\hline \multirow{2}{*}{ Overall Result } & \multicolumn{2}{|c|}{$(\mathbf{n}=\mathbf{5 0})$} \\
\cline { 2 - 3 } & No. of Patient & $\mathbf{\%}$ \\
\hline Complete Cured & 41 & 82.00 \\
\hline Maximum Improvement & 04 & 8.00 \\
\hline Moderate Improvement & 03 & 6.00 \\
\hline Mild Improvement & 02 & 4.00 \\
\hline No Relief & 00 & 0.00 \\
\hline Total & $\mathbf{5 0}$ & $\mathbf{1 0 0}$ \\
\hline
\end{tabular}

management. $45 \%$ of patients were found in age group between 31 to 45 years. It can be thought that young middle aged and married patients are more prevalent due to more family responsibilities. Sound sleep was found in $98.23 \%$, Madhyama Koshta $(65.38 \%)$ were more and maximum patients $(65.38 \%)$ were suffering from Parikartika having symptoms of Mandagani (diminished digestive power) and constipation. Mandagani is said to be the root cause of all diseases in Ayurveda, ${ }^{9}$ Patients having Vata Pittaja Prakriti were found maximum (67.31\%) which showed Vata Dosha predominance relation to patients of Prakriti. $86.54 \%$ of patients were observed to be having irregular bowel habits which might be due to Agnimandya, Vishamashana $(44.23 \%)$ followed by Viruddhashana $(32.69 \%)$. Overall, $35 \%$ of patients were reported having chronicity up to one year and $33 \%$ patients were reported 1-2 years of chronicity because of selection criteria adopted in the study that only chronic cases were included. Fissure at posterior (6 o'clock) position of the anus were observed in $87 \%$ patients because fissure bed at posterior position is mainly due to the impact of direct pressure of stool at posterior aspect of the anal canal during defecation. The sentinel pile is commonly found in cases of chronic fissure-in-ano which develops to guard fissure from more tear of the anal verge, maximum $84 \%$ of patients had developed sentinel pile included in study. These data are well supported by the authentic texts of surgical practice. ${ }^{10}$ In this study, on per rectal digital examination; $83 \%$ patients had spasmodic anal sphincter; it is due to increased intra-rectal pressure and causes delay in healing ${ }^{11}$ and finding also supported by previous research work. The main warning sign of 
Parikartika is Vedana (pain in ano); after three weeks statistically highly significant relief in pain was observed, might be due to relaxation of sphincter spasm after Lord's anal dilatation as well removal of morbid tissue by KSL from fissure bed which promotes healthy and complete wound healing. Smeared Kshara on Ksharasutra is alkaline in nature (pH-10.39) which inhibits the bacterial growth. Hence, formed wound after cut through was in Shuddha Avastha (clean and non-infected wound). Maximum patients showed wound healing after 21 days. Hence, study backings the principle that clean and healthy wounds take minimum of 3 weeks for complete healing. Maximum patients in both groups have relief in oozing within $7^{\text {th }}$ postoperative day, and very less patients had taken 14 days to stop oozing. Discharge of serous is due to the inflammation present around the wound in early days, but use of Jatyadi Taila $(10 \mathrm{ml} /$ rectum $)$ once daily was found helpful in controlling oozing/ discharge. The sitz bath with (PVK) and per rectal instillation of JT certainly is helped to achieve the conditions of Shodhana and Ropana of wound. In $49 \%$ patients, Ksharasutra ligated at fissure bed, sloughed out spontaneously on $4^{\text {th }}$ postoperative day whereas $38 \%$ patients were observed sloughing out of Ksharasutra by $5^{\text {th }}$ postoperative day. Very few patients $(3 \%)$ had taken 6 days to slough out Ksharasutra from fissure bed. Constipation was relieved in all patients within 14 days by combined use of EBH orally acted as Anulomaka (laxative) and per rectal instillation of JT helpful in relieving the Rukshata (dryness), Malabadhhata and anal sphincter spasm by virtue of its Snigdha, Shodhana and soothing properties. Bleeding was stopped after Ksharasutra ligation in all patients within 7 days. Hence, it can be inferred that Ksharasutra ligation was effective to stop bleeding.

\section{Probable mode of action of Ksharasutra}

Ksharasutra contains Apamarga Kshara (Achyranthes aspera Linn.), Snuhi Ksheera (latex of Euphorbia neriifolia Linn.) and Haridra Churna (powder of Curcuma longa Linn.) and prepared by adopting standard operating procedure described in Ayurvedic Pharmacopeia of India (API). ${ }^{12}$ The Apamarga Kshara having properties of Chedana (excision), Bhedana (incision), Ksharana (debridement), Stambhana (haemostatic), Shodhana (purification/sterilization), and Ropana (healing). Chedana and Bhedana properties of Kshara are helpful to excise the sentinel pile as well as fissure bed. ${ }^{13}$ Ksharasutra ligated at fissure bed excises the fibrotic tissue by action of Ksharana and removes unhealthy fibrous tissue and debris; make the wound healthy by Shodhana property. ${ }^{14}$ The Snuhi Ksheera is slightly acidic in nature but also has antibacterial property ${ }^{15}$ which helped to check secondary infection. The Haridra has anti-inflammatory as well as anti-bacterial ${ }^{16}$ properties and hence, it is capable to make the wound clean, healthy, and promote early healing. ${ }^{17}$

\section{Probable mode of action of adjuvant drugs}

The Panchavalkala kwatha ${ }^{18}$ was used for Avagaha Swedana (warm water sitz bath); has Shodhana (purification), Stambhana (astringent), Shotha hara (anti-inflammatory), and Vedana hara (analgesic) properties which helped to relieve pain, local oedema as well as to stop oozing and maintained perianal hygiene. Eranda Bhrishta Haritaki Churna is specially indicated for Vibandha (constipation). ${ }^{19}$ Most of the ingredients used in Jatyadi Taila are Shotha hara, Vedanasthapana and Ropana (wound healing) which are important requirements for healing of the wound. ${ }^{20}$ Jatyadi Taila was instilled per rectal to reduce the swelling and pain as well as for smooth evacuation of faeces. The ingredients of the Taila like Neem (Azadirachta indica A. Juss) ${ }^{21}$ and Daruharidra (Berberis aristata DC.) are proven drugs to check bacterial growth and promote wound healing.

\section{CONCLUSION}

In Parikartika (Chronic fissure in ano with sentinel pile and anal papilla), Ksharasutra ligation is a good alternative to modern surgery as it carries less postoperative pain and easy to perform. Wound remained healthy after slough out of Ksharasutra and average healing time of postoperative wound was within 21 days. There are no any chances of complications like bleeding; infection and also recurrence are almost negligible in this procedure. Hence, it is a good procedure to manage chronic fissure in ano.

\section{ACKNOWLEDGEMENT}

Director IPGT and RA, GAU Jamnagar.

\section{REFERENCES}

1. Shastri AD, editor. Sushruta Samhita of Acharya Sushruta, Chikitsa Sthana. Reprint edition. Ch. 34, Ver. 37. Varanasi: Chaukhambha Sanskrit Sansthan; 2001. p. 147.

2. Goligher J, Dutie H, Nixon H. Surgery of the Anus Rectum and Colon. $5^{\text {th }}$ ed. New Delhi: AITBS Publishers and Distributors; Reprint; 2002. p. 150.

3. Todd P. Prevalence of fissure in ano in males and females, diseases colon and rectum. 1977; 21: 187-92.

4. Jensen SL. Treatment of first episodes of acute anal fissure: Prospective randomised study of lignocaine ointment versus hydrocortisone ointment or warm sitz baths plus bran. Br Med J (Clin Res Ed) 1986; 3; 292: 1167-9.

5. Chowcat NL, Araujo JG, Boulos PB. Internal sphincterotomy for chronic anal fissure: long term effects on anal pressure. $\mathrm{Br}$ J Surg 1986; 73: 915.

6. Shukla N K, Narang R, Nair NG et al. Multi centric randomized controlled clinical trial of Ksharasutra (Ayurvedic Medicated thread) in the management of Fistula in ano. Indian J Med Res 1991; 94: 177-185.

7. Bhuyan C, Dudhamal TS, Gupta SK. A new technique for the treatment of Jeerna Parikartika with special reference to chronic fissure-in-ano. Indian J Anc Med Yoga 2010; 3: 13340.

8. Goligher J, Dutie H, Nixon H. Surgery of the Anus Rectum and Colon. $5^{\text {th }}$ ed. New Delhi: AITBS Publishers and Distributors; Reprint; 2002. p. 154.

9. Shastri K, editor. Ashtanga Hridaya of Vagbhata, Nidana Sthana. Reprint Edition. Ch. 12, Ver. 1. Delhi: Chaukhamba Sanskrit Pratishthan; 1994. p. 154.

10. Williams NS, Bulstrode CJK, O Connell PR. Chronic fissure in ano. Baily and Love's Short Practice of Surgery. $25^{\text {th }}$ ed. Boca Raton: UK Hodder Arnold Part of Hachette; 2008. p. 1252.

11. Goligher J, Dutie H, Nixon H. Surgery of the Anus Rectum and Colon. $5^{\text {th }}$ ed. New Delhi: AITBS Publishers and Distributors; Reprint; 2002. p. 158.

12. Anonymous. Ksharasutra (Medicated thread). Ayurvedic Pharmacopeia of India. $1^{\text {st }}$ ed. Part-II. Vol. II., New Delhi: Dept. of AYUSH, Govt. of India; 2001. p. 209-13.

13. Shastri AD, editor. Sushruta Samhita of Acharya Sushruta, Chikitsa Sthana. $12^{\text {th }}$ edition. Ch. 11, Ver. 3. Varanasi: Chaukhambha Sanskrit Sansthan; 2001. p. 34.

14. Shastri AD, editor. Sushruta Samhita of Acharya Sushruta, Chikitsa Sthana. $12^{\text {th }}$ edition. Ch. 11, Ver. 5. Varanasi: Chaukhambha Sanskrit Sansthan; 2001. p. 34.

15. Rasik AM, Shukla A, Patnaik GK, Dhawan BN, Kulshrestha BK, Srivastava S. Wound healing activity of the latex of Euphorbia neriifolia Linn. Indian J Pharmacol 1996; 28: 1079. 
16. Negi PS, Jayaprakasha GK, Rao JM, Sakariah KK. Antibacterial activity of turmeric oil: A by product from curcumin manufacture. J Agric Food Chem 1999; 47: 297300.

17. Synopsis of turmeric's healing properties. (N. d.). Available from: http:// www.turmeric.co.in/turmeric ayurvedic_use.htm. (Last accessed on 2012 Jan 12).

18. Bhuyan $\bar{C}$. Malasaya Roga Chikitsa Vignyan (Anubhuta

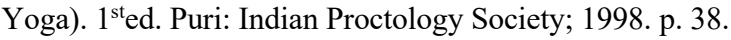

19. Bhatta KG. In: Tripathi ID, editor. Rasendra Sara Sangraha. $2^{\text {nd }}$ ed. Varanasi: Chaukhamba Orientalia; 1998. p. 48-9.

20. Dudhamal TS, Bhuyan C, Baghel MS. Wound healing effect of Jatyadi Taila in the cases of chronic fissure-in-ano treated with Ksharasutra. AYU International Research Journal of Ayurved 2013; 34 (5) (Suppl. 1): 22.

21. Biswas K, Chattopadhyay I, Banerjee RK, Bandyopadhyay $\mathrm{U}$. Biological activities and medicinal properties of Neem (Azadirachta indica). Curr Sci 2002; 82: 1336-45.

\section{Cite this article as:}

Gajiram D. Banothe and T. S. Dudhamal. Management of Chronic fissure in ano by Ksharasutra (medicated thread): A Clinical Prospective Study. Int. J. Res. Ayurveda Pharm. 2020;11(4):45-49 http://dx.doi.org/10.7897/2277-4343.110487

\section{Source of support: Nil, Conflict of interest: None Declared}

Disclaimer: IJRAP is solely owned by Moksha Publishing House - A non-profit publishing house, dedicated to publishing quality research, while every effort has been taken to verify the accuracy of the content published in our Journal. IJRAP cannot accept any responsibility or liability for the site content and articles published. The views expressed in articles by our contributing authors are not necessarily those of IJRAP editor or editorial board members. 